\title{
Effect of Boron and Lime on Yield assessment of Wheat (Triticum aestivum L.)
}

\author{
Princy Thakur and Dibyendu Mukhopadhyay*
}

Department of Soil Science and Agricultural Chemistry, Uttar Banga Krishi Viswavidyalaya, Pundibari, Cooch Behar, West Bengal, India -736165, India

*Corresponding author

\begin{tabular}{l} 
Key w o r d s \\
$\begin{array}{l}\text { Wheat, Lime, } \\
\text { Boron, Seed } \\
\text { treatment, Soil } \\
\text { treatment }\end{array}$ \\
\hline Article Info \\
$\begin{array}{l}\text { Accepted: } \\
10 \text { November } 2018 \\
\text { Available Online: } \\
\text { 10 December } 2018\end{array}$ \\
\hline
\end{tabular}

Keywords

Wheat, Lime

Boron, Seed

treatment, Soil

treatment

10 December 2018

\section{A B S T R A C T}

Wheat (Triticum aestivum L.) production is often affected due to micronutrient status in soil. Micronutrient deficiency in soil including Boron is very much prominent in India, due to prevalent environmental and soil conditions (viz., wide variation in soil $\mathrm{pH}$, organic matter, salt stress, supply of micronutrients etc.) among the various methods of incorporating micronutrients into the soil system, seed treatment with seed priming and seed coating are attractive, easy cost effective and beneficial over the soil and foliar application. A field experiment was conducted with wheat (Cv. K1009) over two years (2014-15 and 2015-16) during Rabi season in an acid soil of Terai region of West Bengal. Liming material was applied to attain an optimum $\mathrm{pH}$ for the growth of the crop. Full dose and half dose of boron as seed treatment and soil application was applied. Combined effect of lime and B (through soil application and seed treatment) was assessed on yield of wheat. The highest yield $\left(5.37 \mathrm{t} \mathrm{ha}^{-1}\right)$ was obtained under seed treatment $\left(\mathrm{T}_{9}\right)$ over soil treatment $\left(4.7 \mathrm{t} \mathrm{ha}^{-1}\right.$ at $\left.\mathrm{T}_{9}\right)$ after the combined effect of full dose of lime and boron with uniform application of $\mathrm{N}, \mathrm{P}$ and $\mathrm{K}$. The performance under seed treatment was better compare to the soil application in terms of yield of wheat.

\section{Introduction}

Wheat (Triticum aestivum L.) is one of the important cereals and India is considered as the third largest producer of wheat in the world with the production of 86,530 thousand mt (FAS; USDA, 2016). But deficiency of micronutrients are wide spread in many Asian countries including India due to wide variation in soil $\mathrm{pH}$, low organic matter, salt stress, prolonged drought, imbalanced NPK fertilizers and supply of micronutrient (Nadrim et al., 2012).
Under the present study, wheat was grown on moderately acidic soil having $\mathrm{pH}$ 4.5-5.5 (due to excessive leaching) i.e. Terai soil of West Bengal. In this region alluvial-acid soil and marshy acid soil are found which are under cultivation. The rice-wheat system is the most important cropping pattern in this region and considered to be the major determinant factor of the agriculture-based economy. The management of an acid soil is required for improving the potential of the soil for higher yield and productivity of the crops. Under the ICAR Network Project (Panda et al., 2012) 
different crops and effect of liming material were studied and found that liming alone increased the yields of different crops by 14$52 \%$ in which the increase production of wheat $(52 \%)$ in West Bengal has been marked followed by Mustard (35\%).

Among the various cereal crops, wheat is considered to have low requirement for $\mathrm{B}$ and is less sensitive for its deficiency. Besides this, its deficiency hamper its nutritional value. Wheat suffers from the nutritional disorders and has been reported from different parts of the world including South Asian countries like India and Pakistan (Rashid et al., 1996, Sharrocks, 1997, Rerkasem and Jamjod, 2004). Hence, B fertilization is the simple and cost effective solution to the problem.

Various methods of the incorporation of the micronutrients are known, of which soil and foliar application are more common. Now-adays, seed treatment techniques with micronutrients comprising seed priming and seed coating are attractive, easy and cost effective over other application technique (Farooq et al., 2012). Based on the above perspectives, the present study was undertaken 1) to assess the individual and combined effect of lime and boron on wheat.2) to study the methods of application of boron on the potential yield of wheat.

\section{Materials and Methods}

\section{Experimental site}

A field experiment was carried out at the agricultural farm of Uttar Banga KrishiViswavidyalaya, Pundibari, Cooch Behar, West Bengal, India. The farm is located within the Terai Agro-climatic zone and its geographic location is $26^{\circ} 19^{\prime} 86^{\prime \prime} \mathrm{N}$ latitude and 89 $233^{\prime} 53^{\prime \prime}$ E longitude. The elevation of the farm is 43 meters above the mean sea level. The field experiment with different treatments (Table 1) was carried out in the same field during the winter season (Rabi season) of 2014-15 and 2015-16.The local topography of the study area is almost flat with good drainage facilities. Before laying out the experimental plots, a set of surface soil samples were collected over the whole experimental area, composite together and tested in the laboratory following the standard methods. The measured physicochemical properties (Table 2) were analysed by the standard method (Jackson, 1967) used as the baseline measurement for the experimental plots.

\section{Experimental designs and treatments}

A set of fifty four experimental plots $(4 \mathrm{~m} \times 3$ $\mathrm{m}$ ) were laid out following randomized block design (RBD) for this experiment and nine treatments combinations (Table 1) with three replications were developed for seed as well as the soil treatment. Treatment $\mathrm{T}_{1}\left(\mathrm{~L}_{0} \mathrm{~B}_{0}\right)$ was control receiving recommended dose of N,P and $\mathrm{K}$ without application of lime and boron and $T_{2}$ to $T_{9}$ received recommended doses of $\mathrm{N}, \mathrm{P}$, and $\mathrm{K}$, and lime and boron having different doses. The composite soil samples from the experimental site were collected and analyzed before the start of the field experiment. Nitrogen ( $\mathrm{N} @ 100 \mathrm{kgha}^{-1}$ ), phosphorus $\left(\mathrm{P}_{2} \mathrm{O}_{5} @ 60 \mathrm{kgha}^{-1}\right)$ and potassium $\left(\mathrm{K}_{2} \mathrm{O} @ 40 \mathrm{kgha}^{-1}\right)$, in the form of urea, single super phosphate, Murate of potash; B as boric acid $(0.5 \%$ as full dose and $0.25 \%$ as half dose) were applied as seed treatment (soaking of seed in boric acid solution for 10-12 hrs then sun dried) and in other case the treatments of B as borax $\left(10 \mathrm{~kg} \mathrm{ha}^{-1}\right.$ as full dose and $5 \mathrm{~kg} \mathrm{ha}^{-1}$ as half dose) were applied to the soil. Similarly full and half doses of lime, i.e., 4.2 tons $\mathrm{ha}^{-1}$ and 2.1 tons $\mathrm{ha}^{-1}$ were applied to the soil prior to 15 days of sowing to manage the acidity of soil. Full dose of P, K and half of the recommended dose of $\mathrm{N}$ were applied as basal and incorporated into the soil. The 
remaining half of the recommended dose of $\mathrm{N}$ was applied as top dressing at 21 days after sowing (DAS), after completion of the first weeding.

\section{Agronomic observations}

The wheat variety of K- 1009 was used for this experiment at the seed rate of $100 \mathrm{~kg} \mathrm{ha}^{-1}$. Sowing was completed in rows (spacing 23 $\mathrm{cm}$ ) in North South direction using a duckfoot tyne at a depth of 2.5 to $3 \mathrm{~cm}$. The height (from ground level) of five randomly selected plants were recorded and averaged from each plot. The crop was harvested from net plot area discarding the border row and final yield of wheat and straw was recorded after sun drying and thrashing. The yields were recorded and harvest index i.e. [(Economic Yield/Biological Yield) $\times 100$ ] of the crop was calculated. Soil samples initially collected were tested for important $\mathrm{pH}, \mathrm{EC}$, oxidisable organic carbon, textural classes, available- $\mathrm{N}$, available- $\mathrm{P}$ and available- $\mathrm{K}$ and available $\mathrm{B}$ by the standard methods (Jackson, 1967).

\section{Statistical analysis}

The statistical analysis for the collected data was done by employing the GEN STAT (Version -11.10.1504). The significant difference between the treatments was tested using ANOVA and LSD. The interaction between the effect of $\mathrm{B}$ and lime was tested using two-way ANOVA.

\section{Results and Discussion}

The important physico-chemical properties (Table 2) of the soils collected from the plots, where boron - treated seeds were sown and those with soil application were determined by the standard methods. In both the cases, the soils were acidic ( $\mathrm{pH}$ from $5.2-5.8$ ) in reaction and non-saline in nature. The soils were sandy loam in texture having oxidisable organic carbon ranging from $0.68-0.78 \%$. The native nutrient $(\mathrm{N}-\mathrm{P}-\mathrm{K})$ status is somewhat low. The extractable-boron $(\mathrm{kg}$ $\mathrm{ha}^{-1}$ ) ranged from $0.72-0.78$ in soils.

Table.1 Details of treatment combination used during field trial A. The plots having the seeds treated with Boron as Boric acid

\begin{tabular}{|c|c|}
\hline Treatments & Doses \\
\hline$T_{1}$ & Control $\left(\mathrm{L}_{0} \mathrm{~B}_{0}\right)$ \\
\hline $\mathbf{T}_{2}$ & NPK+ No Lime + Half boron $\left(\mathrm{L}_{0} \mathrm{BH}\right)$ \\
\hline $\mathbf{T}_{3}$ & NPK+ No Lime + Full boron $\left(\mathrm{L}_{0} \mathrm{BF}\right)$ \\
\hline $\mathbf{T}_{4}$ & NPK+ Half lime+ No boron $\left(L_{H} B_{0}\right)$ \\
\hline $\mathbf{T}_{5}$ & NPK+ Half lime+ Half boron $\left(\mathrm{L}_{H} B_{H}\right)$ \\
\hline $\mathbf{T}_{6}$ & NPK+ Half lime + Full boron $\left(\mathrm{L}_{H} \mathrm{~B}_{\mathrm{F}}\right)$ \\
\hline $\mathbf{T}_{7}$ & NPK+ Full lime+ No boron $\left(\mathrm{L}_{\mathrm{F}} \mathrm{B}_{0}\right)$ \\
\hline $\mathbf{T}_{8}$ & $\mathrm{NPK}+$ Full lime+ Half boron $\left(\mathrm{L}_{\mathrm{F}} \mathrm{B}_{\mathrm{H}}\right)$ \\
\hline $\mathbf{T}_{9}$ & NPK+ Full lime +Full boron $\left(L_{F} B_{F}\right)$ \\
\hline \multicolumn{2}{|c|}{ 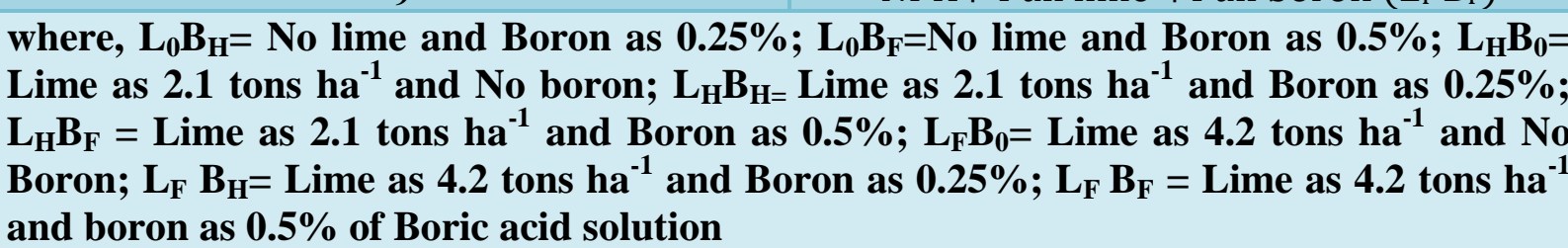 } \\
\hline
\end{tabular}




\section{B. The plots with soil application of Boron as Borax}

\begin{tabular}{|c|c|}
\hline Treatments & Doses \\
\hline $\mathrm{T}_{1}$ & Control $\left(\mathrm{L}_{0} \mathrm{~B}_{0}\right)$ \\
\hline $\mathbf{T}_{2}$ & NPK + No Lime + Half boron $\left(\mathrm{L}_{0} \mathrm{~B}_{\mathrm{H}}\right)$ \\
\hline $\mathbf{T}_{3}$ & NPK + No Lime + Full boron $\left(\mathrm{L}_{0} \mathrm{~B}_{\mathrm{F}}\right)$ \\
\hline $\mathbf{T}_{4}$ & NPK+ Half lime+ No boron $\left(\mathrm{L}_{\mathrm{H}} \mathrm{B}_{0}\right)$ \\
\hline $\mathbf{T}_{5}$ & $\mathrm{NPK}+$ Half lime+ Half boron $\left(\mathrm{L}_{\mathrm{H}} \mathrm{B}_{\mathrm{H}}\right)$ \\
\hline $\mathbf{T}_{6}$ & $\mathrm{NPK}+$ Half lime + Full boron $\left(\mathrm{L}_{\mathrm{H}} \mathrm{B}_{\mathrm{F}}\right)$ \\
\hline $\mathbf{T}_{7}$ & NPK+ Full lime+ No boron $\left(\mathrm{L}_{\mathrm{F}} \mathrm{B}_{0}\right)$ \\
\hline $\mathbf{T}_{8}$ & $\mathrm{NPK}+$ Full lime+ Half boron $\left(\mathrm{L}_{\mathrm{F}} \mathrm{B}_{\mathrm{H}}\right)$ \\
\hline $\mathbf{T}_{9}$ & $\mathrm{NPK}+$ Full lime + Full boron $\left(\mathrm{L}_{\mathrm{F}} \mathrm{B}_{\mathrm{F}}\right)$ \\
\hline \multicolumn{2}{|c|}{ 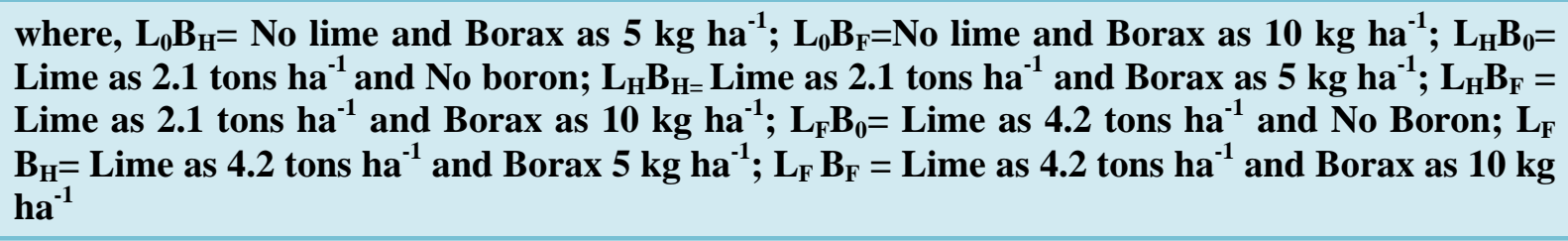 } \\
\hline \multicolumn{2}{|c|}{$\begin{array}{l}\text { N: P:K = 100:60:40 kg ha-1as Recommended dose }(\mathrm{RD}) \\
\text { Lime }=4.2 \text { tons ha-1 as full dose and } 2.1 \text { tons ha- } 1 \text { as half dose } \\
\text { Boric acid }=0.5 \% \text { as full dose and } 0.25 \% \text { as half dose (for seed treatment) } \\
\text { Borax = } 10 \mathrm{~kg} \text { ha-1 as full dose and } 5 \mathrm{~kg} \text { ha-1 as half dose (for soil application) }\end{array}$} \\
\hline
\end{tabular}

Table.2 Physico-chemical properties of soil collected from the different plots under seed treatment and soil application of boron

\begin{tabular}{|c|c|c|}
\hline Parameters & Seed Treatment & Soil Treatment \\
\hline $\begin{array}{l}\text { pH (soil: water } \\
\text { suspension) } \\
\text { pH SMP buffer }\end{array}$ & $\begin{array}{l}5.2 \\
5.8\end{array}$ & $\begin{array}{l}5.3 \\
5.6\end{array}$ \\
\hline $\mathrm{EC}\left(\mathrm{dSm}^{-1}\right)$ & 0.17 & 0.19 \\
\hline Sand $(\%)$ & 52.62 & 50.32 \\
\hline Silt (\%) & 28.18 & 26.14 \\
\hline Clay $(\%)$ & 19.20 & 15.62 \\
\hline Organic carbon (\%) & 0.78 & 0.68 \\
\hline Nitrogen $\left(\mathrm{kg} \mathrm{ha}^{-1}\right)$ & 162 & 157 \\
\hline $\operatorname{Phosphorus(kg~ha-1})$ & 9.8 & 10.5 \\
\hline Potassium $\left(\mathrm{kg} \mathrm{ha}^{-1}\right)$ & 80 & 78.5 \\
\hline Boron $\left(\mathrm{kg} \mathrm{ha}^{-1}\right)$ & 0.78 & 0.72 \\
\hline
\end{tabular}


Table.3 Biometric parameters of wheat under seed treatment and soil treatment

\begin{tabular}{|c|c|c|c|c|c|c|c|c|c|c|c|}
\hline \multirow{2}{*}{\multicolumn{2}{|c|}{ Treatments }} & \multicolumn{5}{|c|}{ Seed Treatment } & \multicolumn{5}{|c|}{ Soil Treatment } \\
\hline & & $\begin{array}{l}\text { Plant } \\
\text { height } \\
(\mathrm{cm})\end{array}$ & $\begin{array}{l}\text { Grain } \\
\text { s per } \\
\text { spike }\end{array}$ & $\begin{array}{c}\text { Test } \\
\text { weight } \\
\text { (gm) }\end{array}$ & $\begin{array}{l}\text { Straw } \\
\text { yield } \\
\left(\mathrm{t} \mathrm{ha}^{1}\right)\end{array}$ & $\begin{array}{c}\text { Grain } \\
\text { yield } \\
\left(\mathrm{t} \mathrm{ha}^{-1}\right)\end{array}$ & $\begin{array}{l}\text { Plant } \\
\text { (cm } \\
\text { height) }\end{array}$ & $\begin{array}{c}\text { Grains } \\
\text { per } \\
\text { spike }\end{array}$ & $\begin{array}{c}\text { Test } \\
\text { weight } \\
\text { (gm) }\end{array}$ & $\begin{array}{c}\text { Straw } \\
\text { yield } \\
\left(\mathrm{t} \mathrm{ha}^{-1}\right)\end{array}$ & $\begin{array}{c}\text { Grain } \\
\text { yield } \\
\left(\mathrm{t} \mathrm{ha}^{-1}\right)\end{array}$ \\
\hline \multicolumn{2}{|c|}{$\mathbf{T}_{1}$} & 89.3 & 32 & 13.43 & 3.40 & 1.90 & 81.45 & 31 & 12.59 & 3.85 & 1.99 \\
\hline \multicolumn{2}{|c|}{$\mathbf{T}_{2}$} & 94.7 & 40 & 17.68 & 5.90 & 3.67 & 87.95 & 37 & 17.55 & 5.50 & 3.32 \\
\hline \multicolumn{2}{|c|}{$\mathbf{T}_{\mathbf{3}}$} & 97.5 & 46 & 21.28 & 6.50 & 4.56 & 91.85 & 43 & 19.14 & 6.32 & 4.12 \\
\hline \multicolumn{2}{|c|}{$\mathbf{T}_{4}$} & 92.2 & 35 & 15.40 & 4.80 & 2.70 & 83.90 & 33 & 15.96 & 4.78 & 2.66 \\
\hline \multicolumn{2}{|c|}{$\mathbf{T}_{5}$} & 95.6 & 42 & 18.93 & 6.20 & 4.10 & 89.65 & 39 & 18.14 & 5.60 & 3.45 \\
\hline \multicolumn{2}{|c|}{$\mathbf{T}_{6}$} & 98.6 & 49 & 22.76 & 6.90 & 4.89 & 95.90 & 46 & 19.89 & 6.50 & 4.41 \\
\hline \multicolumn{2}{|c|}{$\mathbf{T}_{7}$} & 93.9 & 37 & 16.56 & 5.20 & 3.10 & 85.15 & 34 & 16.62 & 5.30 & 3.06 \\
\hline \multicolumn{2}{|c|}{$\mathbf{T}_{8}$} & 97.0 & 44 & 19.97 & 6.40 & 4.40 & 90.80 & 41 & 18.78 & 6.30 & 4.04 \\
\hline \multicolumn{2}{|c|}{$\mathbf{T}_{9}$} & 103.1 & 52 & 24.93 & 7.10 & 5.37 & 99.05 & 48 & 20.76 & 6.60 & 4.78 \\
\hline \multicolumn{2}{|c|}{ Average } & 95.8 & 41.8 & 18.99 & 5.82 & 3.88 & 89.5 & 39.1 & 17.71 & 5.6 & 3.53 \\
\hline \multirow[t]{2}{*}{ Lime } & S.E. & 0.4 & 0.3 & 0.3 & 0.01 & 0.03 & 0.1 & 0.2 & 0.1 & 0.1 & 0.05 \\
\hline & LSD & 1.3 & 0.8 & 0.9 & 0.05 & 0.08 & 0.4 & 0.7 & 0.3 & 0.3 & 0.2 \\
\hline \multirow{2}{*}{$\begin{array}{l}\text { Boro } \\
\text { n }\end{array}$} & S.E & 0.4 & 0.3 & 0.3 & 0.02 & 0.03 & 0.1 & 0.2 & 0.1 & 0.1 & 0.05 \\
\hline & LSD & 1.3 & 0.8 & 0.9 & 0.05 & 0.08 & 0.4 & 0.7 & 0.3 & 0.3 & 0.2 \\
\hline \multirow{2}{*}{$\begin{array}{c}\text { Lime } \\
\times \\
\text { Boro } \\
\text { n }\end{array}$} & S.E & 0.7 & 0.5 & 0.5 & 0.03 & 0.05 & 0.2 & 0.4 & 0.2 & 0.2 & 0.09 \\
\hline & LSD & 2.2 & 1.4 & 1.5 & 0.09 & 0.12 & 0.7 & 1.3 & 0.5 & 0.5 & 0.3 \\
\hline
\end{tabular}


Figure.1 Harvest index (\%) of crops under seed treatment and soil treatment. Error bars indicate the standard deviation (S.D.) at $5 \%$ level of significance

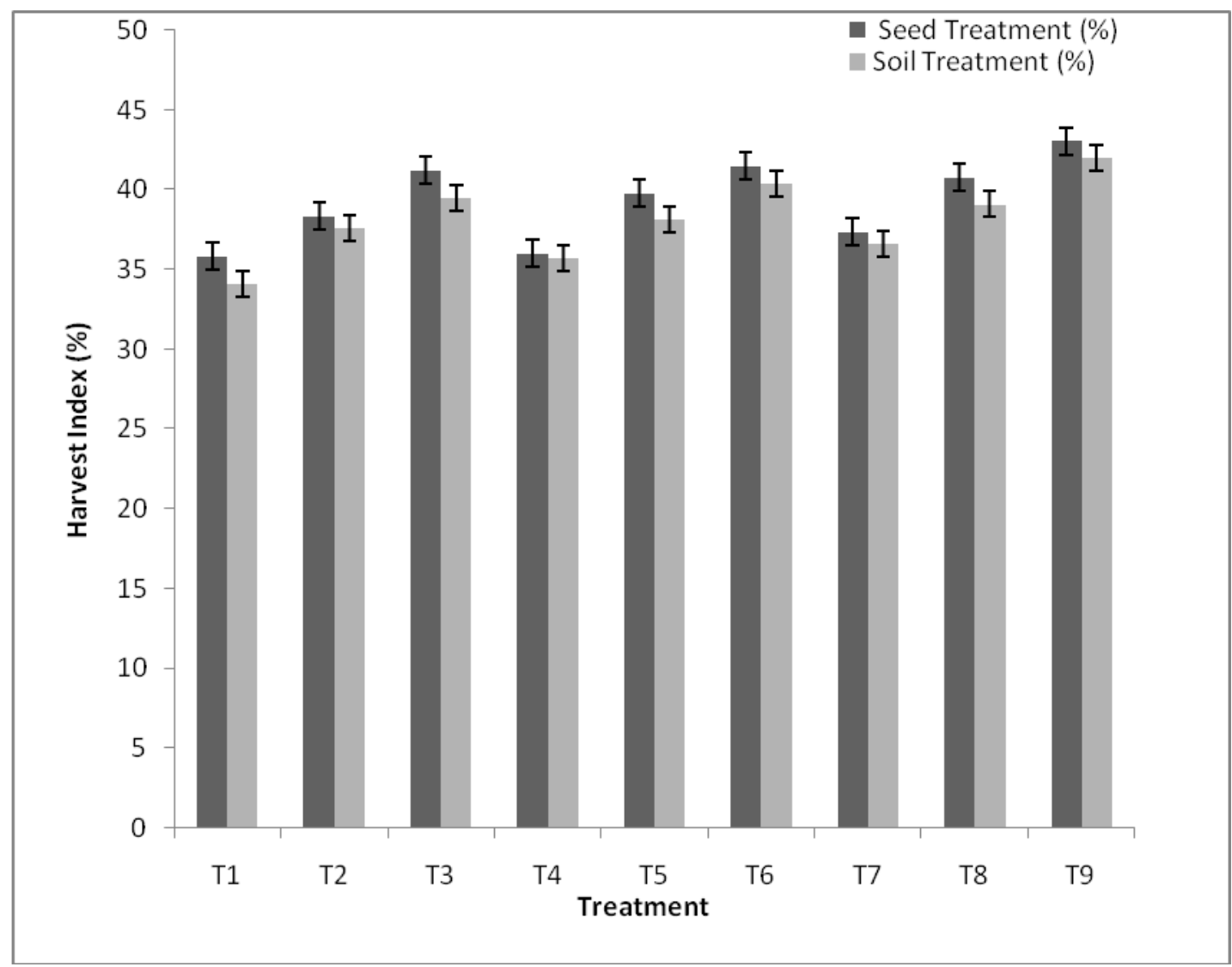

It was observed that (Table 3), there were variations in the agronomic parameters of wheat with the treatment combination. The maximum plant height $(103.1 \mathrm{~cm})$, the number of grains per spikelet (52) and test weight $(24.93 \mathrm{~g})$ were at the treatment $\mathrm{T}_{9}$ where the seed was treated with a full dose of boron. This was again reflected by the maximum (5.37 tha $\left.{ }^{-1}\right)$ of grain and straw (7.10 $\mathrm{t} \mathrm{ha}^{-1}$ ) yield at $\mathrm{T}_{9}$ where there was a full application of nutrients.

The similar trend was observed in the biometric observation of wheat under soiltreated plots. The maximum straw yield (6.60 $\left.\mathrm{t} \mathrm{ha}{ }^{-1}\right)$ and grains yield $\left(4.78 \mathrm{t} \mathrm{ha}^{-1}\right)$ were observed at $\mathrm{T}_{9}$ and the least at $\mathrm{T}_{1}\left(3.85 \mathrm{t} \mathrm{ha}^{-1}\right)$ (untreated control).
It was also observed that boron application along with basal dose of NPK significantly increased the wheat yield. The harvest index (Figure 1) varied from 35.85 to 43.05 under the seed- treated plots while that from $34.10-$ 42 in the soil- treated plots. In both the cases, the maximum harvest index was at the treatment $\mathrm{T}_{9}$ and least and $\mathrm{T}_{1}$.

Kamaruzzaman et al., (2013) studied that the application of $0.5 \mathrm{t}$ lime $\mathrm{ha}^{-1}$ significantly increased most of the growth parameters of wheat compared to that without any lime application It was found that highest yield and yield components of wheat were recorded from recommended fertilizers+ lime $+\mathrm{B}+$ $\mathrm{Mg}$ treated plots and the lowest was recorded in control plot. Saric and Saciragic, (1969) reported that in oats (Avena sativa L.) seed 
priming with $\mathrm{B}\left(0.02 \%\right.$ solution of $\left.\mathrm{H}_{3} \mathrm{BO}_{3}\right)$ had no marked effect on seed germination, yet tillering, panicle length and grain weight were increased by seed priming with B contributing to a grain yield increase of $8.42 \%$ compared with untreated seeds. Mandal et al., (2007) observed that the use of boron produced the highest grain yield due to maximum number of grains spike while significant positive interaction between fertilizer treatments and physiological stages of wheat growth. During one of the experiment by Osundwa et al., (2013), it was revealed that different characters of wheat viz. plant height, tillers plant $^{-1}$, spike length, grains sipke ${ }^{-1}$ and grain yield were significantly increased by the application of lime. In a study, it was found that amendment of soil acidity with lime addition, increased grain yield significantly $(p=0.05)$ in Chepkoilel and Kipsangui area of Kenya and the lowest grain yield were found on control treatment. Mc Donald (2000) observed that the performance of the seeds was relatively better to the soil application, might be due to the faster germination for the partially hydrated seed allowing metabolic events and less imbibition time which might have some effects as reported by Farooq et al., (2012) for an improved nutrient supply. Significant yield differences were there in between the treatments (Table 3). It was apparent both under the seed- treated and soiltreated plots that higher doses of boron and lime had their role to play in increasing the biometric parameters of wheat, resulting in the higher yield of the crop under the acidic soil condition.

From the harvest index (Figure 1), it was apparent that the application of lime and boron had the significant role to play in maximizing the yield of wheat under acid soils. This was also reported by Nardim et al., (2011) that the requirement of B in wheat during the vegetative stage leading to a high response to the grain yield. Since boron is responsible for the translocation of food materials in plants therefore it played vital role in grain setting as well as higher number of grains in wheat. Biswas et al., (2015) also found that there was significant effect of boron on grain and straw yield of wheat. Tahir et al., (2009) in a study observed that Harvest Index was significantly affected by the application of Boron. Hence, application of lime and boron had the significant role to play in maximizing the yield of wheat under acid soils.

The maximum grain yield was observed in the treatment $\mathrm{T}_{9} \quad(\mathrm{NPK}+$ full lime+ full boron)while minimum at the untreated control $\mathrm{T}_{1}$ under seed treatment of boron over that of the soil application of boron in which maximum yield was also observed in the treatment $\mathrm{T}_{9}(\mathrm{NPK}+$ full lime+ full boron) while minimum at the untreated control. This may be due to some interaction between Lime and Boron for nutrient uptake by seeds. Hence, absorption of the Boron by the wheat seed at a definite concentration may play a significant role towards the yield. Liming in acid soil can facilitate the process of establishing the crops for the better effect of the application of boron in soils.

\section{Acknowledgements}

We especially thank Uttar Banga Krishi Vishwavidalya (UBKV), Pundibari, West Bengal, India, for providing the logistics for this work and Mr. Anarul Hoque, RRS, Terai zone, UBKV, for assistance during field trial and laboratory analysis.

\section{References}

Biswas, A., Mukhopodhyay, D. and Biswas, A. 2015. Effect of soil zinc and boron on the yield and uptake of wheat in an acid soil of West Bengal, India. Int. J. Pl. Soil Sci., 6(4): 207-217.

Farooq, M., Wahid, A., Kadambot, H. and 
Siddique, M. 2012.Micronutrient application through seed treatments: A Review: J. Soil Sci. Pl. Nutr. 12:125142.

Foreign Agricultural Service. 2016. United States Department of Agriculture.

Jackson, M.L. 1967. Soil Chemical Analysis. Prentice-Hall of India pvt. Ltd., New Delhi, India.

Kamaruzzaman, M., Mohammad, S.M.R., Rasel, M., and Nurul, Md. I. 2013. Effect of lime on yield contributing characters of Wheat in Barind tract of Bangladesh. J. Agricult. Veter. Sci., 4(6):2319-2380.

Mandal, A., Patra, A.K., Singh, D., Swarup, A. and Masto, R.E. 2007. Effect of long-term application of manure and fertilizer on biological and biochemical activities in soil during crop development stages. Biores. Tech. 98: 3585-3592.

Mc. Donald, M.B. 2000. Seed priming. Seed technology and its biological basis. (Black,M. and J.D.BewleyEds) Academic press UK 287-325.

Nardim, M.A., Awan, I.U., Baloch, M.S., Khan, E.A., Naveed, K., and Khan, M.A. 2012. Response of wheat (Triticum aestivum L.) to different micronutrients and their application methods. J. Anim. Pl. Sci. 22(1): 113119.

Nardim, M.A., Awan, I.U., Baloch, M.S., Khan, E.A., Naveed,K., Khan, M.A., Zubair, M. and Hussain, N. 2011. Effect of micronutrients on growth and yield of wheat. Pak. J Agri. Sci. 48(3):191196.
Osundwa, M.A, Okalebo, J.R., Ngetich, W.K., Ochuodho, J.K., Othieno, C.O., Langat, B. and Omenyo, V.S. 2013. Influence of Agricultural lime on soil properties and wheat (Triticum aestivum L.) yield on acidic soils of Uasin Gishu County, Kenya. American J. Exp. Agr. 3(4): 806-823.

Panda, N., Sarkar, A.K. and Chamuah, G.C. 2012. Soil Acidity. In: Fundamentals of Soil Science. pp 317-328.

Rahman, M.A., Chikushi, J., Lauren, T.G., Duxbery, J.M. and Meisner, C.A. 2004. Liming and nutrient management for sustainable productivity of acidic alluvial soils under rice-wheat cropping system in Bangladesh. Proc. $6^{\text {th }}$ International symposium on plant-soil interaction at low pH.in Japan.304-305.

Rashid, A. 1996. Secondary and micronutrients. In: Soil Science. A. Rashid and K S Memon (Managing Authors). National Book Foundation, Islamabad, Pakistan. Pp. 341-385.

Rerkasem, B. and Jamjod, S. 2004. Boron deficiency in wheat: a review. Field Crops Res. 89: 173-186.

Saric, T. and Saciragic, B. 1969. Effect of oat seed treatment with microelements. Plant Soil 31: 185-187.

Shorrocks, V.M. 1997.The occurrence and correction of boron deficiency. Plant Soil 193: 121-148.

Tahir, M, Tanveer, A., Shah, T.H., Fiaz, N. and Wasaya, A. 2009. Yield Response of Wheat (Triticum aestivum L.) to Boron Application at Different Growth Stages. Pak. J. Life Soc. Sci. 7(1): 39-42.

\section{How to cite this article:}

Princy Thakur and Dibyendu Mukhopadhyay. 2018. Effect of Boron and Lime on Yield assessment of Wheat (Triticum aestivum L.). Int.J.Curr.Microbiol.App.Sci. 7(12): 1133-1140. doi: https://doi.org/10.20546/ijcmas.2018.712.139 